\title{
SHOULD ABORTION BE CRIMINALIZED? REJOINDER TO AKERS, DAVIES AND SHAFFER ON ABORTION
}

\author{
Walter E. Block \\ Harold E. Wirth Eminent Scholar Chair in Economics and Professor of Economics, \\ College of Business Administration, Loyola University New Orleans, New Orleans, USA
}

() MESTE NGO

JEL Category: K18

\begin{abstract}
:
There is a gigantic, stupendous difference between being evicted and being killed, even if, upon occasion, the former leads to the latter. Still, even in these cases, we are entitled to distinguish between these two very different concepts. With regard to the controversy surrounding the abortion issue, the pro-choice side maintains that women have a right to do both; the pro-life forces maintain that women have a right to do neither. Evictionism is the theory that it should be legal for a woman to evict the fetus at any time during her pregnancy, but never, ever, to explicitly kill it. That would be murder. Were evictionism to be the law of the land, with present medical technology, all evicted fetuses in the first two trimesters would die, but they would not be murdered. All evicted fetuses in the last trimester would live, in alternative environments. And, as medical technology improves over time, more and more of those who are evicted at earlier stages of the pregnancy would be able to live. Ultimately, but not at present, evictionism would save the lives of all fetuses.
\end{abstract}

Key words: Abortion, pro-life, pro-choice, evictionism, private property rights

Should abortion be criminalized? Rejoinder to Akers, Davies and Shaffer on Abortion

Libertarianism is non-controversially defined as adherence to two concepts: the non-aggression principle (NAP) coupled with a theory of private

The address of the author:

Walter E. Block

埄”'wblock@loyno.edu property rights based on the homesteading insights of such scholars as John Locke, Murray Rothbard and Hans Hoppe.

It has long been a part of my scholarly output to apply libertarian theory to controversial issues; to expand the envelope by utilizing libertarianism to shed light on difficult challenges.

Abortion is certainly one such case in point. Not only is the world at large at loggerheads with regard to this issue, but so is the libertarian 
community. Murray Rothbard, Ayn Rand and Gary Johnson all take a strong pro-choice position. Ron Paul, in sharp contrast, is vehemently in favor of the pro-life alternative. If this is not an issue on which it is important to apply libertarian theory, then nothing is.

I have been writing about abortion over the years. I first started in the late 1970s, and then again in the early part of the last decade. Apart from a few scholarly responses ${ }^{1}$, and a few supportive letters, my solution to this conundrum, evictionism, has been ignored. I am therefore very grateful to Akers (2012A) (2012B), Davies (2012) and Shaffer (2012) for their criticisms of my viewpoint. I also thank this journal for the opportunity to respond to these three authors. If I cannot convince long term, stalwart, committed libertarians such as these three authors that evictionism is the only correct analysis of this issue, then I cannot convince anyone of it. I shall reply to the specific objections mentioned by this trio, but before I do, some general remarks.

A is swimming 500 miles from shore. B picks up $A$ out of the water, invites $A$ onto his boat, feeds him, nurtures him for a day. Then, B demands that $A$ leave his boat and get back into the water. This will spell certain death for $A$, who cannot

1 Block on evictionism: (Block W. E., Toward a Libertarian Theory of Abortion, 1977) (Block W. E., L'Aborto: Una Legittima Difesa, Undated (1997?)), (Block W. E., Abortion, Woman and Fetus: Rights in Conflict?", 1978), (Block W. E., Stem Cell Research: The Libertarian Compromise, 2001), (Block W. E. Libertarianism, Positive Obligations and Property Abandonment: Children's Rights, 2004), (Block W. E., Homesteading, ad coelum, owning views and forestalling, 2008), (Block W. E., A libertarian perspective on the stem cell debate: compromising the uncompromisible, 2010A), (Dyke \& Block., 2011), (Block W. E., Terri Schiavo: A Libertarian Analysis, 2011A). Critics of evictionism: (Akers, Not My Definition - or Webster's Either - of 'Trespassing', 2012A), (Akers, What if the 'Fetus' Could Shoot Back? 2012B), (Davies, 2012), (Parr, 2011), (Shaffer, 2012), (Wisniewski, A Critique of Block on Abortion and Child Abandonment, 2010A), (Wisniewski, Rejoinder to Block's Defense of Evictionism, 2010B), (Wisniewski, Response to Block on Abortion, Round Three, 2011) Block responds to critics: (Block W. E., Objections to the Libertarian Stem Cell Compromise, 2010B), (Block W. E., Rejoinder to Wisniewski on Abortion, 2010C), (Block W. E., Response to Wisniewski on Abortion, Round Two, 2011B), (Block W. E., Response to Wisniewski on Abortion, Round Three, 2011C), (Block W. E., Evictionism is libertarian; departurism is not: critical comment on Parr, 2011D) swim 500 miles. We assume there is no other boat around. Yes, property owners must remove no longer wanted invitees in the gentlest manner possible, but, sometimes, as in the case of the fetus not yet into the third trimester, and in the case of $A$, this will end up in a killing of an innocent trespasser (one with no mens rea). So, are there positive obligations for the mother, and $B$, to keep these respective people alive? Does the fetus, and A, have a "right to life?" Not for libertarians, who limit themselves to only negative rights. For adherents of this philosophy, there is no right to life, there are no positive (legal) obligations. Note, we are now confining ourselves to the law: what should the law be? We are not discussing morality, a very separate matter. Are $\mathrm{B}$ and the mother who evicts a fetus murderers? Not if we believe that they are the proper owners of the boat and the womb, respectively. I agree this conclusion sounds nasty. It may not pass some "smell" tests. But in my view evictionism is the only theory fully compatible with libertarianism. Those who reject evictionism reject the libertarian emphasis on private property rights, which supports only negative rights. These critics embrace so called positive rights, and thus remove themselves from the libertarian perspective, at least on this one issue. For if the fetus has a right to remain inside the mother's womb against her will, and $A$ has a right to remain on B's boat over B's objections, then libertarianism goes by the board. We must focus on property rights, and libertarian theory, and not allow emotions to get in our way, if we are to clarify the proper position on this matter.

It is important to realize that a trespasser need not have mens rea: a guilty mind. The trespasser need not purposefully want or intend to unlawfully occupy someone else's property. The trespasser could be comatose, or unconscious, or, as in the case of the fetus, unawake, and in any case too young to think or have purposes. But, as long as the fetus, whether invited or not, and A, who is explicitly invited, occupies someone else's property against their will (in the absence of a contract giving the occupier rights), he is a trespasser, and the property owner should have a legal right to remove him, in the gentlest, least rights-destroying manner possible. But, does voluntarily engaging in sexual relations constitute a contract with the fetus? I deny this. A contract 
has to have (at least) two parties. If we ignore the father, and host mother contracts, there can only be an agreement between the mother and the fetus. But, at the time of intercourse, the other contracting party, the fetus (a fertilized egg), does not yet exist. It takes time after ejaculation for the sperm to reach the egg. Thus, even if we think that the fertilized egg (in my view, a human being who bears all rights he will ever have) is capable of contracting (he most certainly is not), he didn't even exist at the time of voluntary intercourse, the supposed basis of his rights to remain through invitation.

I shall now respond to the specific criticisms made in these four publications in the order mentioned above.

\section{A. Akers (2012A)}

States this author: "Evictionism,' huh? That's a new one to me." True, alas, all too true. Despite my best efforts to publicize this libertarian analysis, all too few scholars have even so much as ever heard of it.

Continues Akers (2012A): "The unborn fetus is trespassing into the womb of the woman... Pretty strange 'trespasser' who's there by invitation only." Not so, not so. Unconscious people can be placed on the property belonging to others. If so, they are trespassers, even though, of course, they have no mens rea.

Akers (2012A) avers that "Rape is a different matter..." This implies that the fetus who is a result of this type of assault is not a trespasser. But nothing could be further from the truth. Trespassing has little or nothing to do with invitation. As long as the duly invited guest is no longer desired to be on the premises by the private property owner, ${ }^{2}$ and he refuses to depart, or is unable to do so, he is a trespasser. And, the babies who are a product of rape are every bit as innocent as those who come about as the result of voluntary sexual intercourse. Indeed, rape is a very weak point for the pro-life side of this debate. If they make an exception for this case, they are acting incompatibly with their basic premise of the sanctity of all human life.

\footnotetext{
${ }^{2}$ Whether boat owner in the case of the swimmer, or owner of the womb, the mother, in the case of pregnancy
}

Only those who refuse to make this exception remain within the realm of logical discourse.

\section{B. Akers, 2012B:}

This author starts of by conflating "murdering people before birth" with evicting them from the private property owned by someone else. The two are not at all the same. Yes, if a baby in the third trimester is killed when it could have been saved, that is indeed downright murder. But, if the mother evicts the fetus in one of the first two trimesters, before it would be viable outside the womb given today's medical technology, that certainly amounts to a killing, but not a murder. This would be akin to the boat owner asking the swimmer to leave his premises.

Several of Akers' (2012B) correspondents interpreted evictionism "as a variation on abortion - and an attempt to euphemize same." No. Supporting evictionism is very different from favoring abortion. One allows for the saving of all babies in the third trimester; the other does not. One will save all babies in uturo, eventually, when medical technology progresses sufficiently; the other will not. One is predicated on the libertarian principle of private property rights (the mother is the sole owner of her womb), the other entirely ignores this basic element of libertarianism. It is highly inaccurate to equate the two very different proposals.

Another charges found in Akers (2012B) is that "There is no concern for the innocent child, only for the sinful parent's 'rights' and 'freedom.' Yep, that's judgmental - but l'd rather be judgmental than infanticidal." We are now discussing what libertarian law should be, not the morality of evictionism. It is unfair to tax evictionism with lack of concern for innocent pre-birth babies. It is much the same with the legalization of other victimless crimes, say, prostitution, pornography or addictive drug sales. The correct libertarian position, in my view, on these matters is that all of these acts should be legal. But only the libertine, not the libertarian (Block W. E., 1994) favors actually engaging in these practices. The libertarian, properly speaking, has no position on their actual practice at all, apart from the claim that they should not be against the law. It is precisely the same with evictionism. The libertarian contention is, only, that this should be 
legal. The libertarian, qua libertarian, takes no position whatsoever on whether "concern for the innocent child" is appropriate. Presumably, all men of good will, libertarians too when we are not focused entirely on the legal implications of our philosophy, will be highly "concerned".

Akers (2012B) maintains that her correspondents "compared the baby to an actual trespasser, demonstrating the many places where the analogy fails." However, she vouchsafes us no specifics as to the supposed disanalogy. A mere claim in this regard should not serve as a refutation, not if we are doing a serious philosophical examination.

There may be some commentators who maintain that "freedom' includes the freedom to murder," as Akers (2012B) avers, but I am certainly not one of them, her claims to the contrary notwithstanding. To justify evicting a trespasser, comatose, unconscious, or infantile, from someone else's private property is the very essence of libertarianism. To deny this is to contradict its basic premise: private property rights and the NAP. This author maintains that a person who supports evictionism "realized he was promoting evil." But with no evidence for such a contention, or any explanation, it is difficult to refute such a claim.

According to Akers (2012B) "God said, 'Thou shalt do no murder"'. I have no quarrel with such a statement. But it implies without offering any support for this contention that eviction amounts to murder. The best that can be said for this claim is that it is unproven, and unsupported.

Akers (2012B) "doubt(s) the efficacy of endlessly arguing. My impression is that folks very seldom change their minds on these issues." Here, she commits the fallacy of the performative contradiction ( (Hoppe, 1988) (1989); (Kinsella, 2002)). She argues, in effect, that arguing is inefficacious, and, presumably, should not be engaged in. But, she does so in the midst of arguing that evictionism is wrong headed and incompatible with libertarianism. If she truly objected to argumentation, she should not have published not only Akers (2012A and 2012B) but her numerous, incisive and magisterial arguments against the TSA. They all take the form of argumentation.
Akers' (2012B) "stomach turned at the proabortionists' fine points, the slicing and dicing, the tortured 'reasoning.' These are human lives we're talking about, yet you want them to hinge on whether or not a baby has reached X number of weeks when his mother pronounces sentence on him, or how you or someone you've read defines 'life,' or any number of other bizarre details supposedly specified in the mother's non-existent 'contract.' Forgive me for this incendiary comparison, but your arguments echo the Nazis' as to why it wasn't really murder, was in fact admirable, to kill 'life unworthy of life."'

Placing scare quotes around words such as "reasoning," "life," and especially "contract" is no substitute for rational argument, nor is this practice compatible with libertarianism. It is a misunderstanding of the evictionist position, moreover, to suppose that the right to evict hinges on how old the baby is; no, the only thing determined by the age of the fetus is whether or not it will be viable outside the womb, and this is a matter of medical technology, not libertarian theory. If evictionism smacks of Nazi-ism, then even more so the pro-life position resembles slavery, in that it forces an unwilling woman, for nine months, to act against her will.

According to Akers (2012B), "When you contend for murder, please remember these almostvictims and understand that abortion and evictionism aren't just cute academic arguments: real flesh-and-blood people live or die because you justify and advance such wickedness." Repeating again and again the charge that evictionism is indistinguishable from unjustified killing, e.g., murder, is no substitute for reasoned argument. Name calling (e.g., "wickedness," "Satanic," "balderdash," "stomach turned," "Nazis," etc.) does not further our understanding either. Yes, "real flesh-and-blood people (will) live or die" depending upon the results of these debates. All the more reason, then, to eschew hysteria and name-calling, and to try even the more to adhere to the philosophy that unites us, libertarianism.

Akers (2012B), "close(s) with a brief but brilliant slogan from writer John Zmirak - one that could settle the issues of abortion, evictionism, and all their satanic variations while upholding the Second Amendment: 'Arm the Unborn." 
Suppose, then, that the fetus had a gun, and could use it. Would it be justified for him to do so? Yes, I maintain, if he is in the third trimester, and is in the process of being murdered, not merely evicted. He would be totally justified in using his weapon in self-defense. But suppose he was in one of the first two trimesters, and could not, at present, be viably moved. Would he now be engaging in mere self-defense if he demanded, at the point of a gun, that he remain in or on someone else's private property? No more so than would $A$, the swimmer, be entitled to a place on B's boat, against the will of the latter. Either we take libertarianism seriously, or we do not. If we do, we may not so blithely jettison private property rights, the very essence of our philosophy.

\section{Shaffer}

Shaffer (2012) starts off supporting "peace, liberty, and individualism." I have a quarrel right at the outset with the third of these, at least on libertarian grounds. In my view, libertarianism is grounded on the NAP and private property rights. Peace and liberty are logical implications of these premises. But individualism ${ }^{3}$ is not. The libertarian, qua libertarian, must be indifferent between individualism and collectivism, as long as the latter is understood as the voluntary cooperation of individuals, the only entities capable of human action. ${ }^{4}$ If individualism were really preferable to collectivism on libertarian grounds, then we should all become hermits. Human interaction would be declared illegal. Individualist sports such as running, swimming, singles tennis, etc., would be licit, but collectivist sports such as baseball, football, basketball, hockey, would have to be declared against the law.

I entirely concur with Shaffer's (2012) desire "to take our understanding into ever-deeper levels... to flesh out the details of our thinking." We should

\footnotetext{
${ }^{3}$ Methodological individualism, which I fully support, is a cornerstone of Austrian economics. It is not under discussion at present. Rather, I am objecting to the equation of political individualism and libertarianism.

${ }^{4}$ There is no such thing as a "group," or a "collective," apart from the individuals who comprise it. But this, again, is an Austrian insight, not a libertarian one.
}

attempt "profound inquiries" and eschew "bumper-sticker one-liners." Otherwise, very truly said, "most of us end up with little more than opinions, but no understanding." In this regard I very much appreciate Shaffer's

(2012) statement that my "'evictionism' approach to the abortion issue invites us to explore deeper levels of our understanding." I am greatly in debt to Shaffer (2012) for saying "Walter has accomplished what any intellectual effort should produce: further questioning of the subject matter at hand."

Shaffer (2012) objects to "a number of young 'libertarians' from the 1960s who insisted on introducing their ideas to others by jumping right to such deeper questions as "do you own your children and, if so, can you sell them?'” While I readily admit that such provocations are not likely to convince some people, this may be just the recipe needed for the conversion of others. I am enough of a subjectivist, and a methodological individualist, to believe in "different strokes for different folks." In any case, perhaps the brashest person who ever converted people to libertarianism en masse ${ }^{5}$ was Ayn Rand, with her in-your-face atheism and ringing support for "greed" and "selfishness."

With these preliminaries out of the way, let us now focus on Shaffer's (2012) critique of evictionism. He starts off by announcing his "regard ... (for) 'life' as sacred ... as a quality innate in, perhaps, all of existence." So far, so good. The libertarian NAP is quintessentially dedicated to protecting against murder. I also enthusiastically agree with Shaffer (2012) that human life begins "upon conception" ( (Rubenfeld, 1991); (Kroger, Undated); (Saunders, Undated)) An egg alone will not become a human being, nor will a sperm. But a fertilized egg, placed in the proper environment, will; and of which of us is this not true? Surely, the gap between a sperm and an egg, alone, apart from one another, on the one hand, and a fertilized egg on the other, is a gigantic one. Whereas, in contrast, the difference between a fetus one day before, and one day after, birth, is

\footnotetext{
${ }^{5}$ She did not consider herself a libertarian. Indeed, she heavily criticized libertarians. Nonetheless, the statement in the text is true.
} 
hardly worth mentioning in terms of human development or anything else of relevance. So, yes, conception, not birth, demarcates human life, with all rights pertaining to it.

Here, though, is where Shaffer (2012) and I part company. He states: "I also believe that ... the killing of an unborn child an act of murder."

But this ignores the entire point of evictionism. It implies that the unborn child has a right to be in the mother's womb, on or in her private property, against her will. Shaffer does not appear to leave room, even, for the pregnant lady to evict the unborn child in the case of rape. An unborn child is an unborn child is an unborn child, no matter how it was conceived. If this is so, then, at least, this author gets credit for logical consistency. The pro-life position, if it is to be logically coherent, cannot, must not, make any exception for rape. But, in so doing, this stance leaves it open to the charge that it renounces private property rights, for, clearly in the case of rape, the unborn child is a trespasser. If the mother cannot rid herself of this fetus, whether or not such an act eventuates in its death, then what becomes of the libertarian support of private property rights? It is not merely violated, it is annihilated. But private property rights are the very essence of libertarianism. If Shaffer is serious about his contention that "I also believe that ... the killing of an unborn child an act of murder," and makes no exception for rape, then he cannot be considered a libertarian, at least on this one issue.

States Shaffer: "Because of my disapproval of all political systems - which are universally defined as agencies that enjoy a monopoly on the use of violence within a given territory - I am unwilling to sanction the use of violence to either (a) physically prevent, or (b) punish a woman for having an abortion."

But if this author thinks that abortion is murder (as do I!: it combines eviction with unjustified killing) and is unwilling to countenance any use of violence to stop this type of murder, then what about other types of murder, as between adults? If Shaffer carries through on this point to its logical conclusion, he announces himself as a pacifist, and eschews any sort of violence. In doing so, in making this a bedrock of his philosophy, he once again removes himself from libertarianism, which justifies violent acts in self (or other) defense. If this author does not go that far, and would allow the use of violence in these other cases, then why not when a mother murders her child?

Shaffer asks of himself: "are you saying that, in a society grounded in liberty, people are 'free' to kill one another?" My answer is 'yes.' Even in our present command-and-control world of legalized violence, each of us is 'free to kill ... others. Such 'freedom' does not mean that we may rightfully or morally do so, only that we have the capacity to inflict harm upon others. From a libertarian perspective, the question becomes (as it does in our daily lives): how do we exercise our freedom so as to minimize harm to others?"

There are more errors in this short paragraph than you can shake a stick at. First of all, Shaffer confuses the "is" and the "ought." He rides roughshod over the normative-positive distinction. Of course people are free to kill each other in the sense that they have this (positive) ability. And, just as assuredly, they are not free to do any such thing in that to do so would be to violate the (normative) NAP. As to "harm," it is certainly licit for us to harm each other in ways that do not violate the NAP. For example, $X$ opens a grocery store right next to $Y$ 's similar operation. $X$ has "harmed" $Y$ in the sense that he attracted several of $Y$ 's customers away from $\mathrm{him}$, and in the direction of $\mathrm{X}$. Or boy $\mathrm{J}$ asks girl $K$ out for a date. She agrees. Both of them have "harmed" boy L, who wanted to date K.

Nor is this very acceptable to the libertarian ear: "In my view of the world, a pregnant woman will make her own decision as to whether to abort. I may disapprove of the decision she makes, but I will not resort to - nor sanction - force against her to make her conform to my value." I take an entirely different perspective. In my own view of the world, if a pregnant woman not only evicts her baby from the womb, but does so in a manner that kills it, when it would have been viable apart from her, then she is an outright murderess, and any doctor who helps her do this horrific thing aids and abets her in doing nothing less than murder. Both of them should be prosecuted to the full extent of the law. On the other hand, if she merely evicts her fetus, whether or not it survives this geographical displacement, she is guilty of no crime that a 
libertarian would recognize, any more than B would be guilty of a crime by insisting that the swimmer A depart his premises.

At the very core of our disagreement Shaffer states: "I am also unable to accept Walter's characterization of the unborn child as a 'trespasser.' Such a person came into being through no act or will of its own... Whether the unborn child was conceived voluntarily - as an act of either love or lust - or through the violent act of rape, is irrelevant to the question of its sense of personhood. In the case of rape, the worst that can be said of the unborn person is that it is the product of wrongdoing, not a wrongdoer itself."

I am now happy to acknowledge that my intellectual opponent on this issue is logically consistent. He makes no exception for the baby prompted by rape. ${ }^{6}$ However, I cannot see my way clear to agreeing with him that an "act of will" is a necessary condition for trespass. Thomson ( (1986), (1990), (1991)) offers the case where an unconscious kidney patient is hooked up to that organ of another person. Surely, this counts as a trespass even though the beneficiary of this operation slept through the entire procedure.

Shaffer poses a question to libertarian theorists: "If someone was to deposit a newly-born baby on my front doorstep, would I be entitled to (a) ignore the child, or (b) place it on the curb, neither act worsening the plight of the child? However Walter might answer this question as a philosophic matter, I think I know him well enough to predict that he would not respond in either manner. Would he - or I - have an 'obligation' to the child to come to its rescue? As a matter of some imposed 'duty,' I would answer 'no' to both possibilities. But as a response to our self-interested needs to protect the value of life which is what our philosophic principles should be about in the first place - I have no doubt as to how each of us would behave in this circumstance."

I am entirely in accord with Shaffer's analysis of this matter. For libertarians, there are no positive

6 But then his other objection falls by the wayside. Surely, the product of a rape, of course entirely innocent of such a horrific deed, is a trespasser upon his victim-mother. obligations. We can as a matter of law, allow the baby to stay right where he is, and perish. Of course, as decent moral human beings, we would of course rescue the baby and bring him to the hospital. However, at the very moment in time, there are countless babies, and adults too, who will starve to death this very evening. ${ }^{7}$ Neither Shaffer, nor I, nor any number of people have lifted so much as a finger to help them, otherwise they would not now be perishing. Should we all be punished by law? No. I'm sure I speak for Shaffer as well as myself when I say that the two of us have devoted our entire professional careers to lessening this sort of thing, by promoting laissez faire capitalism and other aspects of the freedom philosophy.

I am also in full and enthusiastic agreement with Shaffer when he denies "The argument on behalf of the woman being able to abort the unborn child often includes the proposition: personhood does not arise until the child is able to sustain itself independently." As this author incisively points out, due to specialization and the division of labor, virtually no adult is able to be independent in this manner. Therefore, he and I fully agree, the unborn baby has as many rights as any other human being. But not, I would insist, the "right" to trespass.

\section{Davies}

Davies (2012) starts out on the wrong foot with an unwarranted attack on prejudice "...to begin with a prejudice (a 'pre-judgment') and then perhaps look around for supporting rationale." But prejudice is merely a reasonable way of dealing with life's experiences. It is, indeed, a synonym for induction. We note that tigers are dangerous creatures. If we see one, we "pre judge" it to be like all the other tigers we have encountered, and attempt to get away from it, without trying to determine if it is an exception to this general rule. There is nothing untoward about this. ${ }^{8} \mathrm{He}$ also errs in equating libertarianism and anarchism. Surely, there are members of the former category who do not fall

\footnotetext{
7 Most of this tragedy, although not all of it, is due to socialism and lack of private property rights in underdeveloped countries.

${ }^{8}$ I owe this example to Walter E. Williams.
} 
into the latter. He also erroneously claims that "Axiomatically, every person has a right to life..." In my view of libertarianism, no one has any such thing as a right to life, for rights imply obligations, and if $U$ has a right to life, $V, W$, etc., have an obligation to support his life. This opens us up to welfare "rights" which no libertarian can countenance.

Davies (2012) then summarizes the positions on abortion of Block (2012), Akers (2012A, 2012B) and Shaffer (2012). Let us see how accurate he is in each case. He concludes with his "own take" on the matter, and we shall follow him there as well.

This author accurately summarizes Block and Whitehead (2005) and is kind enough to characterize it as "creative thinking!" Here is his succinct and correct summary of my view: "It will not satisfy those whose premise is that even the fertilized egg is a human person with an inherent right to life, but it does deal with the third trimester and promises to move ever closer to dealing with even that extreme position. As a compromise, it has a great deal of merit."

But then Davies (2012) goes off the rails: "Its main shortfall as I see it is that while Block is a professor of economics, he deals with this as if to propose a change in the law. The problem there is that in a free society - towards which he is presumably working - there will be no law, for there will be no government, and so law is irrelevant except in the short term; rather, in that free society, economics will be the prime determinant of almost everything. Why, exactly, should the mother have an obligation to preserve the life of the evicted fetus? The answer is partly ethical, yes, but also partly economic. Somebody must pay for the baby's care. Who? Why? Prof. Block has published a great deal about this proposition, so perhaps I missed it, but I saw no reference to that key subject."

There are great difficulties with this account. First, it constitutes an ad hominem attack. Yes, I am indeed a professor of economics, but this hardly precludes me from commenting upon what would constitute just law from the libertarian perspective. Second, of course there can be law without government. Indeed, that institution is the greatest violator of libertarian law, the NAP, in all of history. $^{9}$ Third, despite what I have characterized as his truthful portrayal of my views, I nowhere state that "the mother ha(s) an obligation to preserve the life of the evicted fetus." Indeed, I deny all positive obligations, this one certainly included. Fourth, several of my publications on the subject make it clear that the adoptive parents would pay for the care of the baby they adopt. Why is this even relevant to evictionism?

How does Davies (2012) deal with Akers (2012A)? He starts off by supporting "her frequent denunciations of the government's TSA," with which I enthusiastically concur. Akers has been a one woman burr under the saddle of the TSA, for which all libertarians must be extremely grateful.

Davies (2012) accurately reports that Akers (2012A) scorns my use of the term "trespasser" on the grounds that no invasion of property took place; the fetus came by invitation, by a positive choice on the mother's part (rape cases excepted)." Davies (2012) response is so much on point that I report it here in its entirety:

"This criticism seems to me to rest on a rather narrow definition of the term. It's true that by 'trespass' we normally refer to the act of crossing a forbidden threshold or border, but the condition of being a trespasser also describes someone who is on someone else's property without leave, regardless of how he got there. So for example, a girl may invite her date back home for a nightcap, but when it becomes clear he has something a lot more than cognac on his mind, she changes her mind and asks him to leave. If he refuses, he's trespassing and she is entitled to use whatever force is needed to evict him."

Davies (2012) criticizes Akers' (2012B) claim that "human personhood ... begins at conception." $\mathrm{He}$ does so on the ground that she bases this claim on God's will. I along with Davies am an atheist, so cannot accept her claim on that ground. But I most certainly do agree with her contention that human life begins with the fertilized egg. If left in its proper environment it will survive and prosper; if not, then not. But this is something that can equally be said of all of us.

9 See on this Benson (1989), (1990); Hoppe (2011); Stringham (2007) 
Davies (2012) is surprised by what Shaffer (2012) proposes to do about mothers who abort: nothing!" I cannot go along with Davies' (2012) assessment that this "moves the discussion to an altogether higher plane." In my view, abortion, when mere eviction and the saving of the baby's life were possible, is out and out first degree murder. Thus, letting those responsible go free would appear to move us to an entirely lower plane, one which leaves unpunished such a despicable act. Justice, surely, includes strongly opposing murder, and being willing to employ force to stop it.

Let us now consider Davies (2012) "own take" on this matter. In his view, human life begins in effect when "Reasoning - rationality" appears. "Now, is a fertilized egg able to reason?" asks Davies. He answers: "Of course not. It has no brain, even. The question is absurd. Therefore, the zygote is not a human being and so it has no inherent rights ...Yes, of course it is a potential person, a proto-human, but until it acquires that ability it is not, and the contrary suggestion is ludicrous."

Not so, not so at all, I maintain. After all, the comatose person, the sleeping person, the overtired person, the mentally handicapped person, is not capable of reasoning. The drunkard loses rationality. It would be a strange view that would accord no human rights to any of these people, so as to maintain the legitimacy of denying them to the zygote.

Moreover, Davies (2012) contradicts himself. He says: "We therefore have two parties involved: (1) the mother, who certainly has the right to choose how to dispose of all parts of her own body throughout the process, and (2) the fetus, which has no such right initially but who acquires it at some point and at latest when born. If there is a conflict, the mother's choice must therefore prevail; the fetus' rights are uncertain and variable, the mother's rights are fixed and certain. End of story."

Maybe, end of story for Davies' analysis, but let us not go there quite so fast. According to Davies himself the fetus attains no human rights until rationality comes about. But, surely, this does not obtain until at least some few years after birth. How, then, can the fetus attain any rights at all "at latest when born." If Davies were to stick to his outrageous interpretation, it could be used to support infanticide, since all babies and newborns are irrational. The idea that the fetus can be treated like a thumb nail, or an appendix, and the mother be free "to dispose of all parts of her own body" such as these without any legal penalty, seems nothing short of barbaric.

Davies (2012) is a very strange kind of anarchist. $\mathrm{He}$ equates this state of affairs with the entire absence of all law: "In the future, when government has vanished ... there will be no mechanism for imposing anything on everyone else." No, no, a thousand times no. In any Rothbardian ( (1973), (1998 [1982])) version of anarcho-capitalism, there will be laws against murder, rape, theft, kidnapping, etc. Indeed, it is the state that is the greatest violator of the NAP. People will be forcibly prevented from violating the NAP, and if they do, and there is any justice, they will have severe physical consequences visited upon them.

In the view of Davies (2012): "I hope therefore that the reader will focus on what matters: ending the government era, as soon as can be done, and not get distracted by transient controversies like this one." Not a chance, say I. Even when statism no longer rears its ugly head, we will still have to figure out, determine, what the law should be. The NAP is insufficient for this purpose. It must be combined with a clear understanding of private property rights (who owns the womb), with the right to evict, and with a correct interpretation of when human life begins. Anarchists, who sweep these problems under the rug, as does Davies (2012), do not at all promote liberty.

\section{Conclusion}

I cannot see my way clear to agreeing that Akers (2012A, 2012B), Davies (2012) or Shaffer (2012) have laid a glove on what I call the libertarian theory of abortion, evictionism. I am severely troubled by the fact that none of the three, all libertarians in good standing in so many, many ways, cannot accept this theory as compatible with libertarianism. If they cannot, the hope that non libertarians will anytime soon support evictionism is not very likely. If so, then millions of babies will needlessly perish; evictionism will not be able to save them if it is not implemented, and 
it will not be implemented if so few people support it, the only perspective compatible with libertarianism, in my humble opinion. Ok, so it is not so humble.

\section{Works Cited}

Akers, B. (2012A, 09 06). Not My Definition - or Webster's Either - of 'Trespassing'. Retrieved from LewRockwell.com: http://www.lewrockwell.com/blog/lewrw/archives/120226.html

Akers, B. (2012B, 09 12). What if the 'Fetus' Could Shoot Back? Retrieved from LewRockwell.com: http://www.lewrockwell.com/blog/lewrw/archives/120728.html

Benson, B. L. (1989, Winter). Enforcement of Private Property Rights in Primitive Societies: Law Without Government. The Journal of Libertarian Studies, 9(1), 1-26. Retrieved from http://mises.org/journals/jls/9_1/9_1_1.pdf

Benson, B. L. (1990). Customary Law with Private Means of Resolving Disputes and Dispensing Justice: A Description of a Modern System of Law and Order without State Coercion. The Journal of Libertarian Studies, Vol. IX, No. 2, 25-42. Retrieved from http://mises.org/journals/jls/9_2/9_2_2.pdf

Block, W. E. (1977, 09). Toward a Libertarian Theory of Abortion. The Libertarian Forum, 10(9), 6-8. Retrieved from http://www.mises.org/journals/lf/1977/1977_09.pdf

Block, W. E. (1978, 04). Abortion, Woman and Fetus: Rights in Conflict?". Reason, 18-25.

Block, W. E. (1994). The Journal of Libertarian Studies: An Interdisciplinary Review. Libertarianism and Libertinism, 11(1), 117-128. Retrieved from http://www.mises.org/journals/jls/11_1/11_1_7.pdf

Block, W. E. (2001, 09 3). Stem Cell Research: The Libertarian Compromise. Retrieved from LewRockwell.com: http://www.lewrockwell.com/block/block5.html

Block, W. E. (2004). Libertarianism, Positive Obligations and Property Abandonment: Children's Rights. International Journal of Social Economics, 31(3), 275-286. Retrieved from http://www.emeraldinsight.com/Insight/viewContainer.do?containerType=Issue\&containerld=1 8709

Block, W. E. (2008). Homesteading, ad coelum, owning views and forestalling. The Social Sciences, 3(2), 96-103. Retrieved from http://medwelljournals.com/new/5/archivedetails. php?id=5\&jid=TSS\&theme $=5 \&$ issueno $=12$

Block, W. E. (2010A). A libertarian perspective on the stem cell debate: compromising the uncompromisible. Journal of Medicine and Philosophy, 35, 429-448. Retrieved from http://jmp.oxfordjournals.org/content/35/4/429.full?keytype=ref\%3B\%2520http\%3A\%2F\%2Fjm p.oxfordjournals.org\%2Fcgi\%2Freprint\%2Fjhq033\%3Fijkey\%3DoczT7ytzmoAD1cz\&keytype=r ef\%2520\&ijkey=oczT7ytzmoAD1cz

Block, W. E. (2010B). Objections to the Libertarian Stem Cell Compromise. Libertarian Papers, 2(34). Retrieved from http://libertarianpapers.org/2010/34-block-objections-to-the-libertarian-stemcell-compromise/

Block, W. E. (2010C). Rejoinder to Wisniewski on Abortion. Libertarian Papers. Retrieved from http://libertarianpapers.org/2010/32-block-rejoinder-to-wisniewski-on-abortion/

Block, W. E. (2011A). Terri Schiavo: A Libertarian Analysis. Journal of Libertarian Studies, 22, 527536. Retrieved from http://mises.org/journals/jls/22_1/22_1_26.pdf

Block, W. E. (2011B). Response to Wisniewski on Abortion, Round Two. Libertarian Papers, 3(Art. 4). Retrieved from http://libertarianpapers.org/2011/4-block-response-to-wisniewski-on-abortionround-two/ 
Block, W. E. (2011C). Response to Wisniewski on Abortion, Round Three. Libertarian Papers, 3(Art. 37). Retrieved from http://libertarianpapers.org/2011/37-block-response-to-wisniewski-onabortion/

Block, W. E. (2011D). Evictionism is libertarian; departurism is not: critical comment on Parr. Libertarian Papers, 3(Art. 36). Retrieved from http://libertarianpapers.org/2011/36-evictionismis-libertarian-departurism-is-not-critical-comment-on-parr/

Block, W. E. (2012, 08 30). A Not So Funny Thing Happened to Me in Tampa. Retrieved from LewRockwell.com: http://lewrockwell.com/block/block208.html

Block, W. E. (Undated (1997?)). L’Aborto: Una Legittima Difesa. Claustrofobia, 1(3), 16-22.

Block, W., \& Whitehead, R. (2005). Compromising the Uncompromisable: A Private Property Rights Approach to Resolving the Abortion Controversy. Appalachian Law Review, 4(2), 1-45. Retrieved from http://www.walterblock.com/publications/block-whitehead_abortion-2005

Davies, J. (2012, 09 23). Abortion. Retrieved from Strike the root: http://strike-the-root.com/abortion

Dyke, J., \& Block., W. E. (2011). Explorations in Property Rights: Conjoined Twins. Libertarian Papers, 3(Art. 38). Retrieved from http://libertarianpapers.org/2011/38-dyke-block-conjoined-twins/

Hoppe, H.-H. (1988). From the Economics of Laissez Faire to the Ethics of Libertarianism. In e. Walter Block \& Llewellyn H. Rockwell, Man, Economy, and Liberty: Essays in Honor of Murray N. Rothbard Auburn, AL.: Mises Institute.

Hoppe, H.-H. (1989). A Theory of Socialism and Capitalism. Boston: Kluwer Academic Publishers.

Hoppe, H.-H. (2011, 04 10). State or Private Law Society. Retrieved from LewRockwell: http://www.lewrockwell.com/hoppe/hoppe26.1.html

Kinsella, S. (2002, 09 19). Defending Argumentation Ethics: Reply to Murphy \& Callahan. Retrieved from anti-state.com: http://www.anti-state.com/article.php?article_id=312

Kroger, D. J. (Undated). The Moment of Conception Marks the Beginning of a Human Life. Retrieved from Scribd: http://www.scribd.com/doc/37133489/The-Human-Life-Begins-at-Conception

Parr, S. (2011). Departurism and the Libertarian Axiom of Gentleness. Libertarian Papers, 3(34). Retrieved from http://libertarianpapers.org/articles/2011/lp-3-34.doc

Rothbard, M. N. (1973). For a New Liberty. New York: Macmillan. Retrieved from http://www.mises.org/rothbard/newliberty.asp

Rothbard, M. N. (1998 [1982]). The Ethics of Liberty. New York: New York University Press. Retrieved from http://www.mises.org/rothbard/ethics/ethics.asp

Rubenfeld, J. (1991). On the Legal Status of the Proposition that "Life Begins at Conception". Retrieved from Yale Law School - Faculty Scholarship Series. Paper 1568. : http://digitalcommons.law.yale.edu/fss_papers/1568

Saunders, W. L. (Undated). Crossing the Nuremberg Line. Retrieved from Touchstone: http://www.touchstonemag.com/archives/print.php?id=15-09-020-v

Shaffer, B. (2012, 09 17). Of Children and Fetuses. Retrieved from LewRockwell.com: http://lewrockwell.com/shaffer/shaffer259.html

Stringham, E. e. (2007). Anarchy and the Law: The Political Economy of Choice. Somerset, NJ: Transaction Publishers.

Thomson, J. J. (1986). Rights, Restitution and Risk. Cambridge: Harvard University Press.

Thomson, J. J. (1990). The Realm of Rights. Cambridge: Harvard University Press.

Thomson, J. J. (1991, Autumn). Self-Defense. Philosophy and Public Affairs, 20(4), 283-310.

Wisniewski, J. B. (2010A). A Critique of Block on Abortion and Child Abandonment. Libertarian Papers, 2(16). Retrieved from http://libertarianpapers.org/2010/16-wisniewski-block-onabortion/ 
Wisniewski, J. B. (2010B). Rejoinder to Block's Defense of Evictionism. Libertarian Papers, 2(Art. 27). Retrieved from http://libertarianpapers.org/articles/2010/lp-2-37.pdf

Wisniewski, J. B. (2011). Response to Block on Abortion, Round Three. Libertarian papers. Retrieved from http://libertarianpapers.org/2011/6-winiewski-response-to-block-on-abortion-round-three/

Received for publication: $\quad 17.11 .2013$

Revision received: $\quad 03.12 .2013$

Accepted for publication: $\quad 21.12 .2013$

\section{How to cite this article?}

Style - APA Sixth Edition:

Block, W. E. (2014, 01 15). Should abortion be criminalized? Rejoinder to Akers, Davies and Shaffer on abortion. (Z. Čekerevac, Ed.) FBIM Transactions, 2(1), 33-44. doi:10.12709/fbim.02.02.01.04

Stile - Chicago Fifteenth Edition

Block, Walter E. "Should abortion be criminalized? Rejoinder to Akers, Davies and Shaffer on abortion." Edited by Zoran Čekerevac. FBIM Transactions (MESTE) 2, no. 1 (01 2014): 33-44.

Style - GOST Name Sort:

Block Walter E Should abortion be criminalized? Rejoinder to Akers, Davies and Shaffer on abortion [Journal] = Should abortion be criminalized? // FBIM Transactions / ed. Čekerevac Zoran. - Belgrade : MESTE, 01 15, 2014. - 1 : Vol. 2. - pp. 33-44. - ISSN 2334-704X (Online); ISSN 2334-718X.

Style - Harvard Anglia:

Block, W. E., 2014. Should abortion be criminalized? Rejoinder to Akers, Davies and Shaffer on abortion. FBIM Transactions, 15 01, 2(1), pp. 33-44.

Style - ISO 690 Numerical Reference:

Should abortion be criminalized? Rejoinder to Akers, Davies and Shaffer on abortion. Block, Walter E. [ed.] Zoran Čekerevac. 1, Belgrade : MESTE, 01 15, 2014, FBIM Transactions, Vol. 2, pp. 33-44. ISSN 2334-704X (Online); ISSN 2334-718X. 